\title{
Incidence and prognostic factors of knee extension deficits following anterior cruciate ligament reconstruction: A systematic review and meta-analysis of randomised controlled trials
}

\author{
Nalan Ektas [1]; Corey Scholes [1]; Meredith Harrison-Brown [1]; Maha Jegatheesan [3]; \\ Ashwin Rajesh [3]; Garry Kirwan [2]; Christopher Bell ${ }^{3 *}$
}

[1] EBM Analytics, NSW, Australia

[2] Physiotherapy Department, Queen Elizabeth II Jubilee Hospital, QLD, Australia

[3] Orthopaedics Department, Queen Elizabeth II Jubilee Hospital, QLD, Australia

*Corresponding author. Christopher.Bell@health.qld.gov.au

\begin{abstract}
Background and aims

Knee extension deficits complicate recovery from ACL injury and reconstruction, however the incidence of knee extension loss is not well defined. The aim of this review was to identify the incidence of loss of extension (LOE) following $A C L$ rupture and reconstruction, explore the definitions of knee extension deficits reported and identify prognostic factors affecting LOE incidence.
\end{abstract}

\section{Methods and analysis}

A systematic search was conducted in Medline, Cochrane Library and PEDro for studies in publication up to September 2019, with no restrictions on publication year. References were screened and assessed for inclusion using predetermined eligibility criteria. Randomised controlled trials (RCTs) that quantified knee angle, loss of extension or incidence of extension deficit were included for quality assessment and data extraction. Statistical summaries were generated and meta-analyses performed in two parts to examine: (i) the probability of a 
medRxiv preprint doi: https://doi.org/10.1101/2020.11.26.20239046; this version posted November 30, 2020. The copyright holder for this preprint (which was not certified by peer review) is the author/funder, who has granted medRxiv a license to display the preprint in It is made available under a CC-BY-ND 4.0 International license.

datapoint being zero incidence compared to a non-zero incidence, and (ii) the relationship between the predictors and non-zero LOE incidence.

\section{$\underline{\text { Results }}$}

A sample of 8594 papers were retrieved using the search criteria, with 48 studies meeting eligibility criteria. Pooled results from 4065 participants were included for analysis, with 3965 participants who had undergone ACLR. The proportion of included studies judged at an overall low risk of bias was small (6\%). The analysis revealed median LOE incidence of $15.9 \%$ (IQR $1.4-46.5)$ at a median follow up from treatment of 4.9 months (IQR 1.9 - 24). Median LOE incidence was $23 \%$ (IQR 8.4 - 50.0) for the subset of studies reporting up to 12 months of follow up. The observed group and study were the most important predictors for whether a datapoint reported an incidence of extension deficit. Time to follow up $(P<0.001)$ and graft type $(P=0.02)$ were found to have a significant influence on non-zero LOE incidence $(\%)$.

\section{$\underline{\text { Conclusions }}$}

This review examined the definitions for the measurement and interpretation of postoperative knee extension, and established the trajectory of knee extension deficit after ACL injury and reconstruction. While factors associated with loss of extension were identified, the trajectory of knee extension deficits were difficult to infer due to discrepancies in measurement techniques and patient variation. Clinicians should expect up to 1 in 3 patients to present postoperatively with loss of extension of at least 3 degrees, which may partially resolve over time. Future work should focus on the development of a standardised framework for postoperative measurement and reporting of LOE.

PROSPERO registration number CRD42018092295 
medRxiv preprint doi: https://doi.org/10.1101/2020.11.26.20239046; this version posted November 30, 2020. The copyright holder for this preprint (which was not certified by peer review) is the author/funder, who has granted medRxiv a license to display the preprint in It is made available under a CC-BY-ND 4.0 International license .

\section{INTRODUCTION}

Anterior cruciate ligament (ACL) rupture can have a long-lasting negative impact on a person's health and quality of life. Treatments for ACL rupture comprise conservative non-operative management (such as activity modification, bracing or physical and activity based therapies), surgical repair, biological therapies or reconstruction of the ligament offered as a first-line treatment in some patients or following failed nonoperative management in others ${ }^{1} . \mathrm{ACL}$ reconstruction (ACLR) is a common treatment strategy employed to limit the long term complications following ACL rupture. Patients who undergo ACLR present with fewer subsequent meniscal injuries, lower incidence of subsequent surgery, and significantly improved activity levels compared to patients receiving non-operative management of their $A C L$ rupture ${ }^{2}$ and with promising return to sport or activity rates observed in those who have had the procedure ${ }^{3}$.

Complications following $A C L$ reconstruction (ACLR), though rare, can include missed concomitant injuries, tunnel malposition, infection, tunnel osteolysis, fixation failure, fracture, increased knee stiffness, graft site morbidity, and thromboembolic events ${ }^{4,5}$. Knee stiffness, presenting as either loss of extension and/or loss of flexion, is a common presentation following acute $A C L$ injury and reconstruction, resulting in poorer functional outcomes and greater incidence of osteoarthritis ${ }^{6}$. Loss of knee extension is less tolerated than flexion loss, and contributes to limitations in athletic performance, functional deficits and increased risk of patellofemoral arthritis at extension deficits of 5 degrees or more $e^{6,7}$. The aetiology for loss of extension (LOE) is multifactorial, ranging from anterior-intercondylar notch scar tissue or graft impingement, capsulitis, technicalities of the surgery and choice of rehabilitation protocol ${ }^{7}$.

Extension deficits remain a common cause of failure and revision surgery following primary $\mathrm{ACLR}^{8}$. While knee extension loss may be resolved with additional interventions, such as arthroscopy, manipulation under anaesthesia, pharmacological or physical therapies ${ }^{9}$, there is limited evidence available that identifies the point at which extension loss becomes detrimental to an individual's functional recovery. While the degree of extension at early follow- 
medRxiv preprint doi: https://doi.org/10.1101/2020.11.26.20239046; this version posted November 30, 2020. The copyright holder for this preprint (which was not certified by peer review) is the author/funder, who has granted medRxiv a license to display the preprint in It is made available under a CC-BY-ND 4.0 International license.

up (4 weeks) was determined to be strongly coupled with the incidence at later phases of recovery (12 weeks follow-up $)^{10}$, the true incidence of deficits are difficult to ascertain due to a lack of consistent criteria and poor definitions for determining loss of knee range of motion (ROM) across the literature ${ }^{9}$. The reported incidence of knee stiffness after surgical reconstruction of the ACL ranges from $2-35 \%{ }^{6}$, with one retrospective study of 100 patients reporting the incidence of knee stiffness at $12 \% 6$ months following ACL reconstruction ${ }^{11}$. Specific incidence of loss of extension is also varied. A recent study of 229 patients reported $25.3 \%$ incidence at four weeks follow up ${ }^{12}$, while reviews of historical ACLR literature ${ }^{7}$ report up to $59 \%$ incidence of extension loss following ACLR. However extension loss is not commonly reported as a primary outcome for investigation across the literature. As such, the natural trajectory of knee extension following $A C L$ rupture and true incidence of extension deficits after surgical reconstruction remains largely unknown, limiting the ability to develop standardised benchmarks for postoperative monitoring of knee extension recovery after ACL reconstruction.

\section{Objectives}

The primary objective of this review was to identify the incidence of loss of knee extension angle in patients diagnosed with ACL rupture electing to undergo formal treatment under the care of a registered clinical provider (including non-operative and arthroscopic ACL reconstruction) compared to the contralateral limb or control patients, as reported within randomised control studies. The secondary objectives were to explore the definitions of knee extension deficits reported and the factors affecting the incidence of extension deficits.

\section{METHODS}

This review was reported as per the Preferred Reporting Items for Systematic Review and Meta-analysis (PRISMA) statement ${ }^{13}$. A protocol for the systematic review was established a priori $^{14}$ and registered on the PROSPERO International Prospective Register of Systematic Reviews, registration number CRD42018092295. 
medRxiv preprint doi: https://doi.org/10.1101/2020.11.26.20239046; this version posted November 30, 2020. The copyright holder for this preprint (which was not certified by peer review) is the author/funder, who has granted medRxiv a license to display the preprint in perpetuity.
It is made available under a CC-BY-ND 4.0 International license .

\section{Eligibility criteria}

The PICOS (Population, Intervention, Comparison, Outcomes, Study Design) framework was used to formulate the research question and define eligibility criteria (Table A) for the literature search $^{15}$.

Table A. Eligibility criteria for study inclusion

\begin{tabular}{|c|c|c|}
\hline Criteria & Inclusion & Exclusion \\
\hline Population & $\begin{array}{l}\text { Adults diagnosed with } A C L \text { rupture. } \\
\text { Exclusions for patient sex, age or activity level were not applied. }\end{array}$ & $\begin{array}{l}\text { Participants diagnosed with multiple- } \\
\text { ligament rupture or patellar } \\
\text { dislocation secondary to } A C L \\
\text { rupture. }\end{array}$ \\
\hline Intervention & $\begin{array}{l}\text { Formal interventions used in the standard care and management } \\
\text { of ACL rupture, including: } \\
\text { - Arthroscopic reconstruction of the ACL using autograft } \\
\text { or allograft with any preparation and independent } \\
\text { drilling of the femur and tibia and anatomical graft } \\
\text { placement (footprint centre to footprint centre), and } \\
\text { - Conservative management using } \\
\circ \text { Surgical repair of the ligament or } \\
\circ \quad \text { Injectable therapies (e.g. platelet-rich-plasma) } \\
\circ \text { Rehabilitation or physical exercise therapy }\end{array}$ & $\begin{array}{l}\text { Revision ACLR procedure, or ACL } \\
\text { reconstruction or repair associated } \\
\text { with joint preserving surgeries for } \\
\text { unicompartmental degenerative } \\
\text { disease treated with: } \\
\text { - Tibial or femoral osteotomy } \\
\text { - Meniscus transplantation } \\
\quad \text { Meniscal prosthesis } \\
\text { implantation } \\
\text { - Joint arthroplasty. }\end{array}$ \\
\hline Comparators & $\begin{array}{l}\text { Minimum knee extension angle or extension deficit reported in the } \\
\text { contralateral non-affected limb or in individuals unaffected by ACL } \\
\text { rupture (identified as "healthy controls") }\end{array}$ & \\
\hline Outcomes & 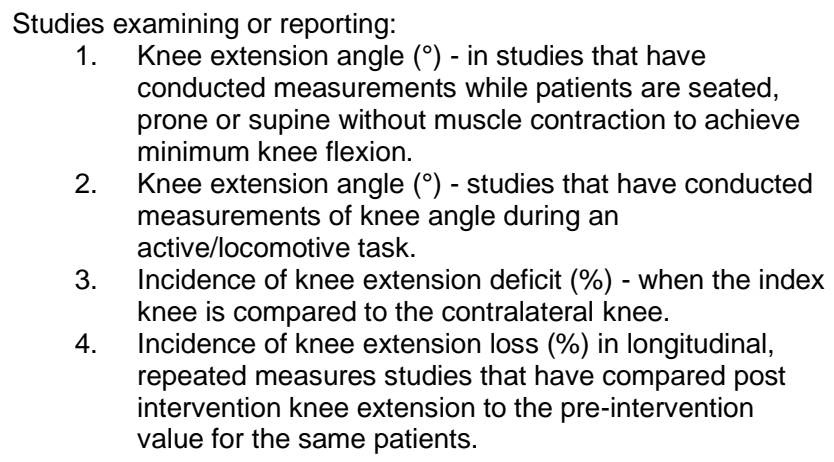 & $\begin{array}{l}\text { Studies that did not report variability } \\
\text { measures around the extension } \\
\text { angle or loss of extension angle were } \\
\text { excluded. }\end{array}$ \\
\hline Study Design & $\begin{array}{l}\text { Randomised controlled trials. No restrictions on publication year } \\
\text { were applied. } \\
\text { N.B. Systematic reviews identified during the search strategy } \\
\text { were used to source additional primary materials but were not } \\
\text { included in the analysis. The results of meta-analyses were } \\
\text { included as a study in the analysis if they meet aforementioned } \\
\text { inclusion criteria. }\end{array}$ & $\begin{array}{l}\text { Studies not published in English } \\
\text { language. }\end{array}$ \\
\hline
\end{tabular}


medRxiv preprint doi: https://doi.org/10.1101/2020.11.26.20239046; this version posted November 30, 2020. The copyright holder for this preprint (which was not certified by peer review) is the author/funder, who has granted medRxiv a license to display the preprint in It is made available under a CC-BY-ND 4.0 International license.

\section{Information Sources}

A comprehensive literature search of the following electronic databases was undertaken from their date of inception until September 2019: Pubmed for Medline, Cochrane Library from EBM Reviews (complete via Ovid SP) and Physiotherapy Evidence Database (PEDro). The search terms comprised keyword combinations and medical subject headings (MeSH) relating to three key domains identifying the pathology (ACL tear OR rupture), intervention or treatment strategy (conservative or surgical reconstruction) and outcomes of interest (extension deficit, loss of extension, stiffness, arthrofibrosis or range of motion). A comprehensive search strategy is presented in Supplementary Material A.

\section{Study identification, selection and data extraction}

The PRISMA flow process for systematic reviews ${ }^{13}$ was used to identify, screen, and assess the eligibility and inclusion of studies to the review. Citations identified during the initial search were uploaded to a web-based bibliographic software (Paperpile LLC, Vienna, Austria) for study management and removal of duplicate records. Study identification was performed iteratively, with reference lists of identified systematic reviews searched to identify further references and retrieved from Medline using an application programming interface ${ }^{16}$. Reference lists of eligible studies were also retrieved to identify additional studies for screening (Figure 1). A custom algorithm was coded to conduct a keyword search within identified titles based on inclusion and exclusion criteria automatically identify titles for abstract screening, flag for manual title screening or exclude from further screening (Table B). Study screening for inclusion of studies to the review and data extraction was performed independently by a core team (BLL, CS, GK, NE, MJ, MHB) with discrepancies resolved with discussion. 
medRxiv preprint doi: https://doi.org/10.1101/2020.11.26.20239046; this version posted November 30, 2020. The copyright holder for this preprint (which was not certified by peer review) is the author/funder, who has granted medRxiv a license to display the preprint in It is made available under a CC-BY-ND 4.0 International license .

Table B. Logic rules for custom algorithm coded for preliminary title screening during systematic review.

\begin{tabular}{|c|c|c|c|}
\hline Inclusion keyword & Logic & Exclusion keyword & Action \\
\hline $\begin{array}{l}\text { Multiple inclusion keywords found in } \\
\text { title }\end{array}$ & AND & Exclusion keyword not found in title & Flag for abstract screen \\
\hline Inclusion keywords not found in title & AND / OR & Exclusion keyword found in title & Flag as excluded \\
\hline Inclusion keyword/s found in title & AND & Exclusion keyword not found in title & Flag for manual title screen \\
\hline
\end{tabular}

Study and population characteristics, as well as intervention or surgical data and outcomes were extracted from included studies for investigation of the primary and secondary objectives of the review (Table C). Web-based forms were used (G Suite, Google, California, USA) for data extraction over three tiers: study, group, and time-point, with distinct variables and outcomes captured at each level depending on whether the data was unique to the study, an observed group within a study or an observed time-point. Screening and extracted data was stored on a cloud-based database (G Suite, Google, California, USA) and summarised to perform statistical analysis and meta-analysis where deemed eligible.

Table C. Data items extracted for the review.

\begin{tabular}{llll}
\hline Study items & Demographic items & $\begin{array}{l}\text { Intervention / treatment } \\
\text { items }\end{array}$ & Outcomes \\
& & & \\
\hline First author & Number of participants & Intervention mode & Time-point for data collection \\
Study title & Gender (\% female) & & Average knee extension angle \\
Year & Average age at treatment & For ACLR: & Average loss of knee \\
Study design & Average height & Fixation type & extension angle (deg) \\
Number of unique groups & Average weight & Graft type & Knee extension loss incidence \\
Comparator & Concomitant injuries & Graft tissue & (\%) \\
Knee extension threshold & Comorbidities & Graft preparation & Significance of findings \\
Definition of extension deficit / & Average time to intervention & Bundle & \\
LOE & Average follow up period & Graft placement - approach & \\
Measurement method & & and strategy & \\
Movement paradigm & & Whether notchplasty was & \\
& & performed & \\
& & &
\end{tabular}


medRxiv preprint doi: https://doi.org/10.1101/2020.11.26.20239046; this version posted November 30, 2020. The copyright holder for this preprint (which was not certified by peer review) is the author/funder, who has granted medRxiv a license to display the preprint in It is made available under a CC-BY-ND 4.0 International license .

\section{Risk of bias}

Independent scoring of risk of bias for included studies was performed using the Revised Cochrane risk-of-bias tool for randomized trials; RoB2 ${ }^{17}$. The RoB2 comprises grading the risk of bias across five distinct domains: randomisation process, deviations from intended interventions, missing outcome data, measurement of the outcome, and selection of the reported result. A single observer (MHB) performed the risk of bias assessment relative to the outcome of interest (loss of knee extension angle) using the Excel tool available at riskofbias.info. Each domain was rated a judgement of "low", "some concerns" or "high" risk of bias based on the answers to the signalling questions. Domain ratings using the algorithm were overridden if considered inaccurate relative to the type of study. Overall risk of bias for included studies was scored "Low risk" where the study was judged to be at a low risk of bias across all domains; overall risk of bias was scored as "Some concerns" where the assessor raised some concern in at least one domain, but not at "High risk" for any domain; studies were judged at overall "High risk" where a high risk was captured in at least one domain, or some concerns were noted in multiple domains ${ }^{17}$. Heterogeneity across the studies was assessed using the $\mathrm{I}^{2}$ statistic ${ }^{18}$ on the maximum LOE reported within a study group and publication bias evaluated from the degree of funnel plot asymmetry ${ }^{19}$.

\section{Statistical analysis}

Continuous variables were summarised using median and interquartile ranges, categorical variables were summarised as percentages (\%). Primary outcomes, knee extension angle and loss of knee extension, were re-coded such that full extension was defined as zero degrees of flexion. The incidence of LOE was estimated from studies that reported an average angle (mean or median) and variance measures (interquartile range or standard deviation), using a normal distribution function in Excel (v1912, Build 12325.20288, Microsoft, USA), with the summary statistics and a threshold of 3 degrees as inputs. Knee extension angles were estimated for studies reporting heel height differences (HHD) using a previously described 
medRxiv preprint doi: https://doi.org/10.1101/2020.11.26.20239046; this version posted November 30, 2020. The copyright holder for this preprint (which was not certified by peer review) is the author/funder, who has granted medRxiv a license to display the preprint in It is made available under a CC-BY-ND 4.0 International license .

conversion ${ }^{20}$. A forest plot was constructed using the maximum LOE within a study group for studies with a non-zero incidence of extension loss ${ }^{21}$.

To identify factors that may be associated with the reported LOE incidence, the analysis was conducted in two parts. The first part examined the probability of a datapoint being zero incidence compared to a non-zero incidence (classification analysis). The LOE incidence was re-coded to a binary categorical variable (detected; not detected). The predictor set was manually identified from the data items extracted. The main criteria for inclusion of a predictor was i) sufficient variation in responses; and ii) sufficient coverage in reporting (low rate of missingness). A feature reduction technique based on mutual information (MI) criterion was implemented to reduce the number of categorical predictors ${ }^{22}$. The slope of the drop in MI was used to determine the inclusion of categorical variables, then combined with continuous data types as predictors for the classification model. A regression tree ${ }^{23}$ was applied to the binary LOE categorisation using the reduced predictor set identified using the dedicated statistics and toolbox in a matrix based programming language (Matlab v9.7.0.1190202 (2019b), Mathworks Inc, USA). A bootstrap-aggregated decision tree was applied to the binary LOE categorisation using the reduced predictor set via a treebagger model with 5 -fold crossvalidation. The second part of the meta-analysis subsetted the data to non-zero incidence and assessed the relationship between the predictors and LOE incidence. A weighted (study sample size) generalized mixed-effects linear model was applied to the reduced predictor set with the non-zero LOE incidence. Overall model fit was assessed with adjusted $\mathrm{R}^{2}$. Predictor coefficients and p-values were summarised for the included fix effects.

\section{RESULTS}

\section{Study selection and characteristics}

The database search strategy combined with citation retrieval returned a total of 8594 nonduplicate records for title screening. A sample of 48 randomised trials ${ }^{24-71}$ met the inclusion criteria and were examined (Figure 1). The studies included were published between 1987 
medRxiv preprint doi: https://doi.org/10.1101/2020.11.26.20239046; this version posted November 30, 2020. The copyright holder for this preprint (which was not certified by peer review) is the author/funder, who has granted medRxiv a license to display the preprint in

perpetuity.
It is made available under a CC-BY-ND 4.0 International license .

and 2019 and were randomised on the time from surgery to extension measurement (recovery trajectory) $(6.3 \%)$, postoperative management (rehabilitation $12.5 \%$, range of motion restriction $25.0 \%$ ) and variations in surgical technique (graft type $45.9 \%$, graft placement $2.1 \%$ and graft fixation\%). A summary of studies is available in Supplementary Material B.

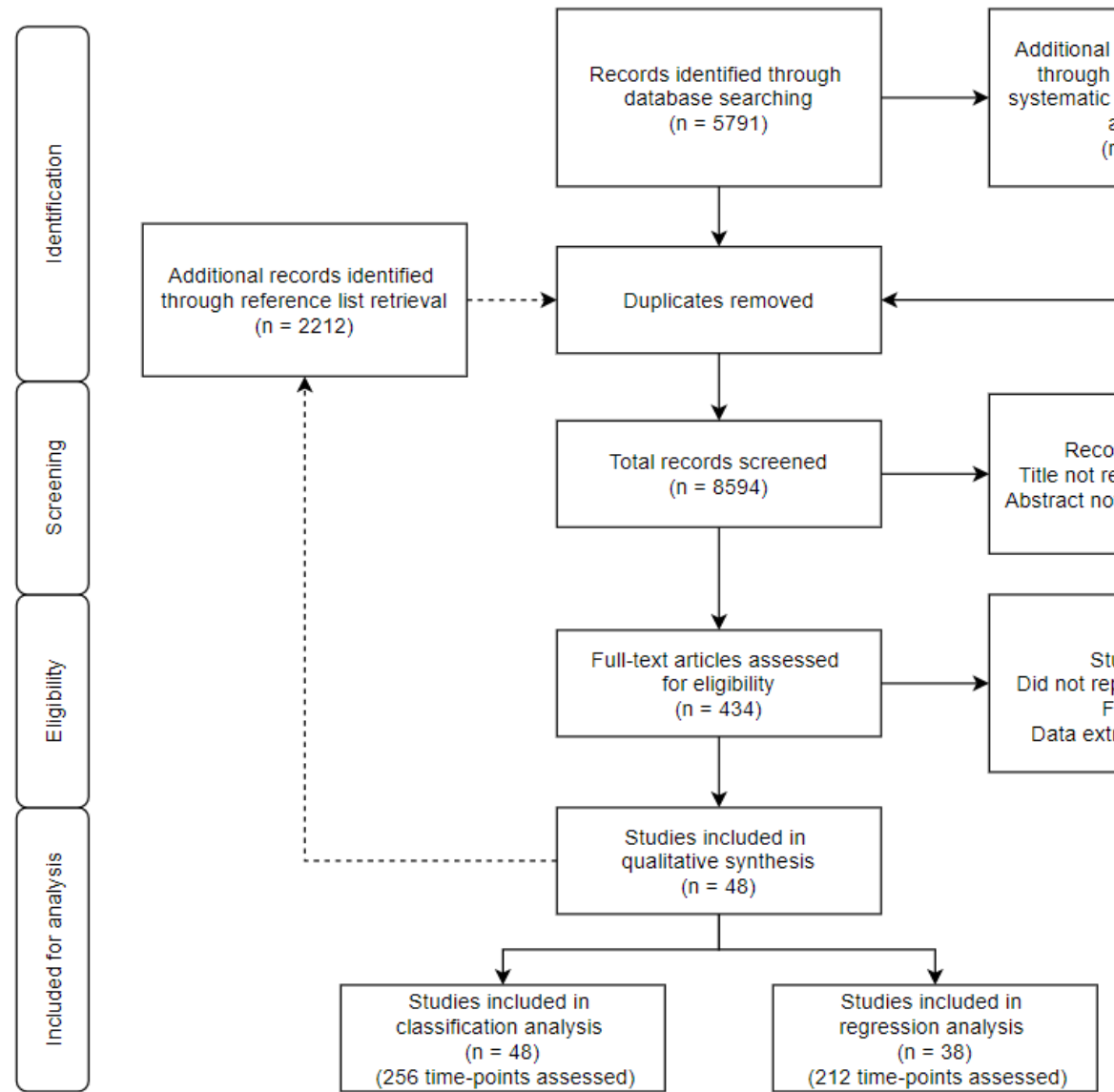

Figure 1. PRISMA flow diagram for study inclusion and data extraction for analysis.

The proportion of included studies judged at an overall low risk of bias was small (6\%), with $44 \%$ and $50 \%$ of studies scoring at least some concerns or high overall risk of bias respectively (Figure 2). 
medRxiv preprint doi: https://doi.org/10.1101/2020.11.26.20239046; this version posted November 30, 2020. The copyright holder for this preprint (which was not certified by peer review) is the author/funder, who has granted medRxiv a license to display the preprint in It is made available under a CC-BY-ND 4.0 International license .

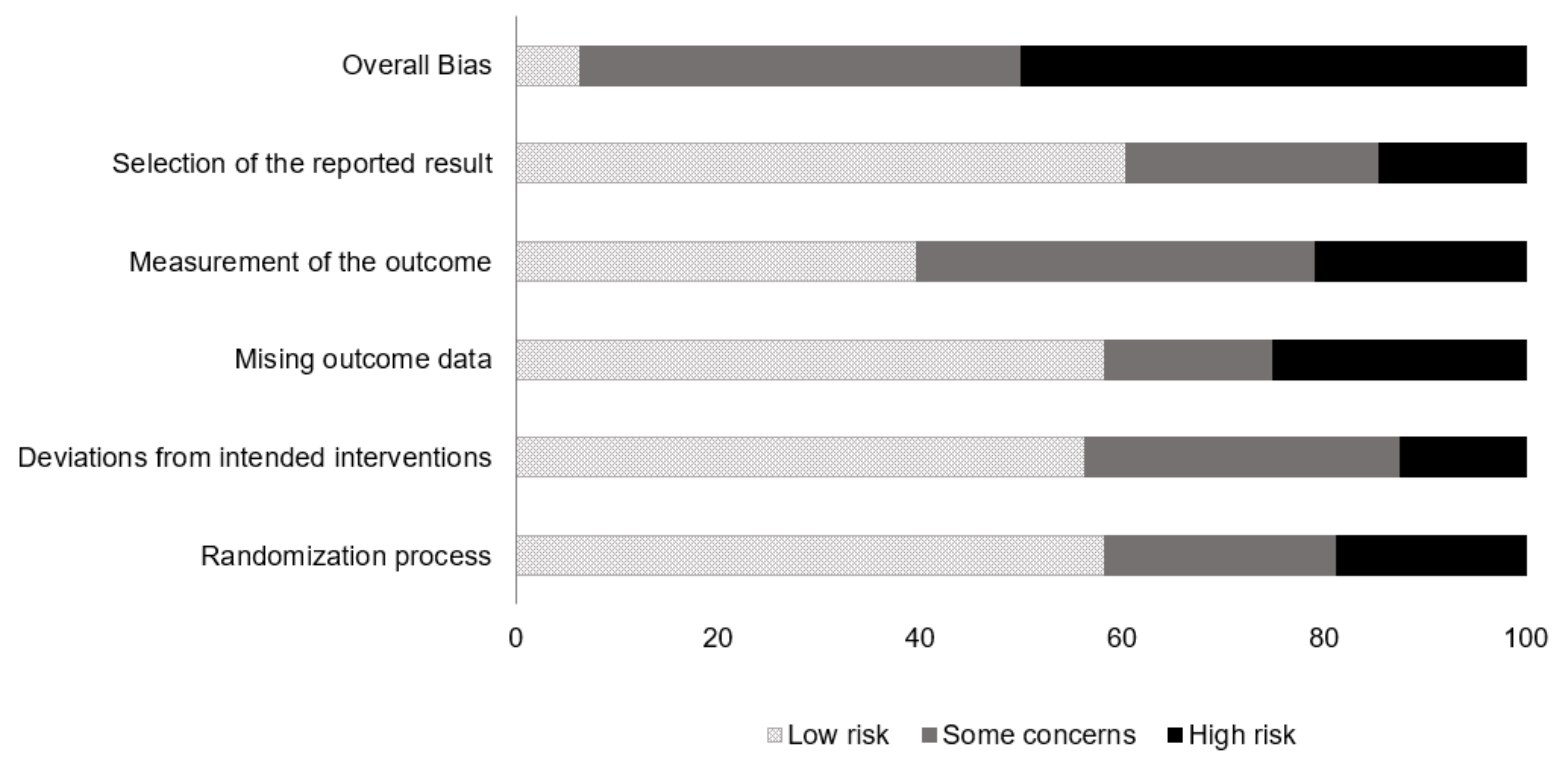

Figure 2: Domain level risk of bias summary and overall risk of bias across included studies.

\section{Patient demographics}

The data extraction revealed 4065 patients who were treated subsequent to ACL rupture with a median age at treatment of 28 (IQR 26.1 - 31.0) with $31.7 \%$ (IQR 21.2 - 43.9) female. 3965 patients underwent ACLR; 100 patients were treated without surgical intervention (physiotherapy / rehabilitation). Height, weight and presence of comorbidities for included participants across studies were poorly reported (83\% not reported) while gender was captured at a higher rate (94\%). The median time to any intervention from injury was 39.1 weeks (IQR 18.9- 73.9) with a maximum of 37 months.

The surgical details extracted from the included articles varied for notchplasty, fixation methods, graft tissue, source, preparation, number and placement of tunnels and the approach (Table D). 
medRxiv preprint doi: https://doi.org/10.1101/2020.11.26.20239046; this version posted November 30, 2020. The copyright holder for this preprint (which was not certified by peer review) is the author/funder, who has granted medRxiv a license to display the preprint in It is made available under a CC-BY-ND 4.0 International license .

Table D: Distribution of surgical technique characteristics within included papers (\%). PT: Patella tendon: ST-only: Semitendinous-only; STG: Semitendinous and gracilis; TA: Tibialis anterior; Auto: Autograft; Allo: Allograft.

\begin{tabular}{|c|c|c|c|c|c|c|c|}
\hline Notchplasty & Fixation & Graft Tissue & Graft Source & $\begin{array}{l}\text { Graft } \\
\text { preparation }\end{array}$ & Tunnel & Approach & Placement \\
\hline Routine (17.5) & $\begin{array}{l}\text { Combination } \\
\text { (37.9) }\end{array}$ & PT (40.8) & Auto (86.4) & $\begin{array}{l}\text { Bone-tendon } \\
(40.8)\end{array}$ & Single (66.0) & $\begin{array}{l}\text { Anteromedial } \\
(30.1)\end{array}$ & $\begin{array}{l}\text { Anatomic- } \\
\text { centre (36.9) }\end{array}$ \\
\hline $\begin{array}{l}\text { As Required } \\
(3.9)\end{array}$ & Screw (35.0) & ST-only (13.6) & Allo (8.7) & $\begin{array}{l}\text { Quadruple } \\
\text { (29.1) }\end{array}$ & Double (10.7) & $\begin{array}{l}\text { Transtibial } \\
(29.1)\end{array}$ & $\begin{array}{l}\text { Anatomic - } \\
\text { Other (13.6) }\end{array}$ \\
\hline Never (4.9) & $\begin{array}{l}\text { Suspension } \\
(8.7)\end{array}$ & STG (36.9) & $\begin{array}{l}\text { Not Reported } \\
\text { (4.9) }\end{array}$ & Double (18.5) & $\begin{array}{l}\text { Not Reported } \\
\text { (23.3) }\end{array}$ & $\begin{array}{l}\text { Rear } \\
(2.9)\end{array}$ & $\begin{array}{l}\text { Non anatomic/ } \\
\text { Isometric } \\
(11.7)\end{array}$ \\
\hline \multirow[t]{3}{*}{$\begin{array}{l}\text { Not Reported } \\
(73.8)\end{array}$} & $\begin{array}{l}\text { Not Reported } \\
(18.4)\end{array}$ & $\mathrm{TA}(1.0)$ & & Other (1.9) & & $\begin{array}{l}\text { Arthrotomy } \\
\text { (3.9) }\end{array}$ & $\begin{array}{l}\text { Not Reported } \\
(37.9)\end{array}$ \\
\hline & & Other (2.9) & & $\begin{array}{l}\text { Not Reported } \\
(9.7)\end{array}$ & & $\begin{array}{l}\text { Not Reported } \\
\text { (34.0) }\end{array}$ & \\
\hline & & $\begin{array}{l}\text { Not Reported } \\
(4.8)\end{array}$ & & & & & \\
\hline
\end{tabular}

\section{Outcomes}

The median incidence of LOE was 15.9\% (IQR 1.4 - 46.5) at a median follow up from treatment of 4.9 months (IQR 1.9 - 24) across all group and time points for included papers. Definition of "full extension" of the knee to determine degree of extension loss varied across included studies (refer to Supplementary Material B). The method and conditions of measurement were also poorly reported (Table E), with the majority of studies defining full knee extension as relative to the contralateral limb $(75 \%)$ or anatomical zero as determined by goniometry (12.5\%). A proportion of studies (12.5\%) did not report the definition of full knee extension. $10.4 \%$ of studies documented knee extension loss using heel-height differences. Knee extension measured with a goniometer, compared to the contralateral limb, with a 3 degree threshold to define a loss of extension, appeared to be the most common approach (Table E). The reporting of LOE incidence was also limited, with half the included studies $(50.0 \%)$ requiring a t-norm conversion from knee angle summary statistics to an estimated incidence of LOE (\%) at a cutoff threshold of 3 degrees. Cutoff thresholds to determine the incidence of extension deficit (relative to full extension) also varied between studies ( $3^{\circ}$ cutoff $(64.6 \%)$ or $5^{\circ}$ degrees cutoff $\left.(35.4 \%)\right)$. 
medRxiv preprint doi: https://doi.org/10.1101/2020.11.26.20239046; this version posted November 30,2020 . The copyright holder for this preprint (which was not certified by peer review) is the author/funder, who has granted medRxiv a license to display the preprint in It is made available under a CC-BY-ND 4.0 International license.

Table E: Distribution of measurement characteristics (\%).

\begin{tabular}{lllll}
\hline Movement type & Position & Measurement Tool & $\begin{array}{l}\text { Knee angle } \\
\text { definition }\end{array}$ & $\begin{array}{l}\text { Extension Loss } \\
\text { Comparator }\end{array}$ \\
\hline Active (10.4) & $\begin{array}{l}\text { Straight leg - Prone } \\
(18.7)\end{array}$ & Goniometer (56.3) & $3^{\circ}(64.6)$ & Contralateral (75.0) \\
Passive (43.8) & $\begin{array}{l}\text { Straight leg - Supine } \\
(31.25)\end{array}$ & Manual (2.1) & $5^{\circ}(35.4)$ & $\begin{array}{l}\text { Anatomical zero } \\
(12.5)\end{array}$ \\
Not Reported (45.8) & Not Reported (47.9) & Ruler (10.4) & Not Reported (12.5) \\
& & Other (4.1) & \\
& Not Reported (27.1) & \\
\hline
\end{tabular}

\section{Meta-analysis of eligible studies}

The $\mathrm{I}^{2}$ based on the maximum LOE reported from each study was $92.1 \%$, with an overall effect size of $36 \%(95 \% \mathrm{Cl} 30.0-42.7)$ using a random effects model (Figure 3). The funnel plot (Figure 4) reinforced the heterogeneity of the data, and indicated that studies with a lower precision tend to report a higher maximum LOE incidence. 
medRxiv preprint doi: https://doi.org/10.1101/2020.11.26.20239046; this version posted November 30, 2020. The copyright holder for this preprint (which was not certified by peer review) is the author/funder, who has granted medRxiv a license to display the preprint in

perpetuity.
It is made available under a CC-BY-ND 4.0 International license.

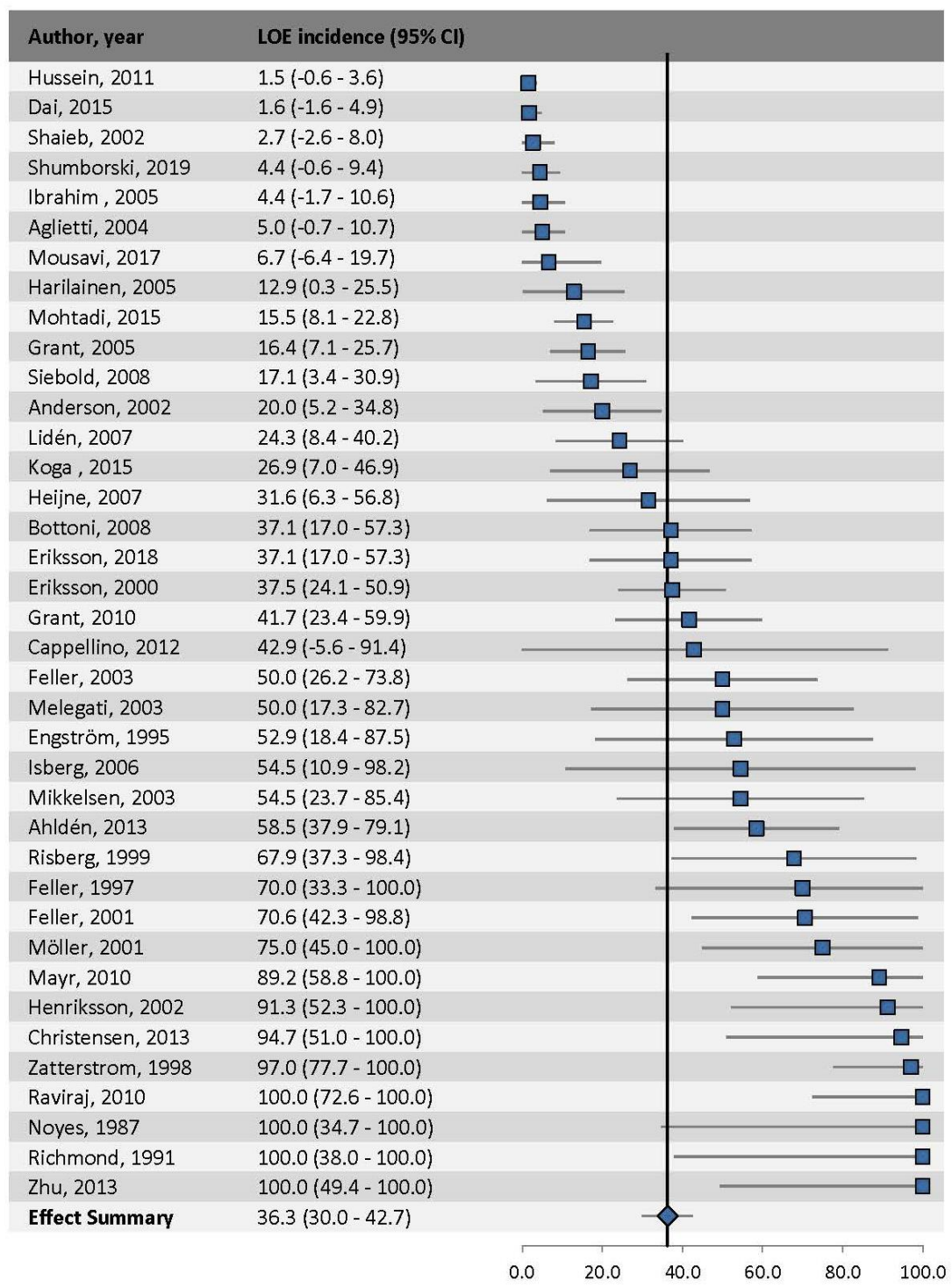

Figure 3 Maximum extension loss reported within a study group and across any time-point, and overall effect size for LOE for included studies with a non-zero incidence of extension loss $24-29,31-38,40-45,48-54,56,58-60,62-64,68,69,71$. 


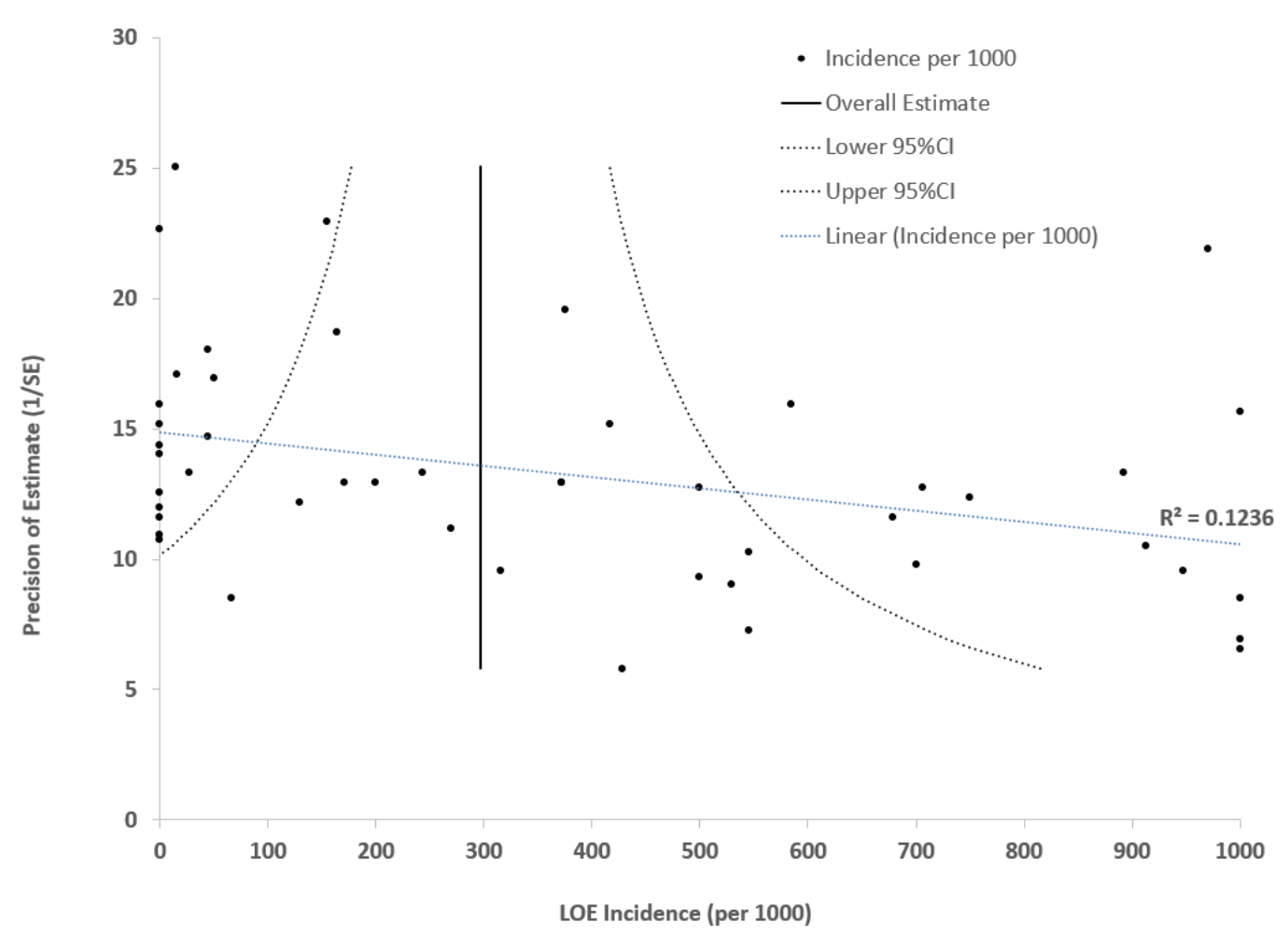

Figure 4 Funnel plot of maximum LOE incidence reported in included studies.

\section{Classification analysis}

A sample of 256 timepoints with 36 fields collected on each timepoint were available for the classification analysis. The data was zero-inflated with a high proportion of loss of extension incidence (LOE) $<5 \%$ (Figure 5). The reduced predictor set for classification component of analysis, after screening with the $\mathrm{Ml}$ feature reduction technique included the following variables: paper and group ID; time of follow up; average age at follow up; graft type; movement paradigm; sample size, graft placement/approach; randomisation factor; tissue type. The misclassification error for the treebagger model was found to be $14.5 \%$, suggesting that the reduced predictor set provided a reasonable fit to the data. The model indicated that the study and observed group within the study were the most important factors for whether a timepoint was reported as undetected (incidence $<1 \%$ ) or otherwise, followed by time to follow up and graft type (Figure 6). 
medRxiv preprint doi: https://doi.org/10.1101/2020.11.26.20239046; this version posted November 30, 2020. The copyright holder for this preprint (which was not certified by peer review) is the author/funder, who has granted medRxiv a license to display the preprint in It is made available under a CC-BY-ND 4.0 International license .

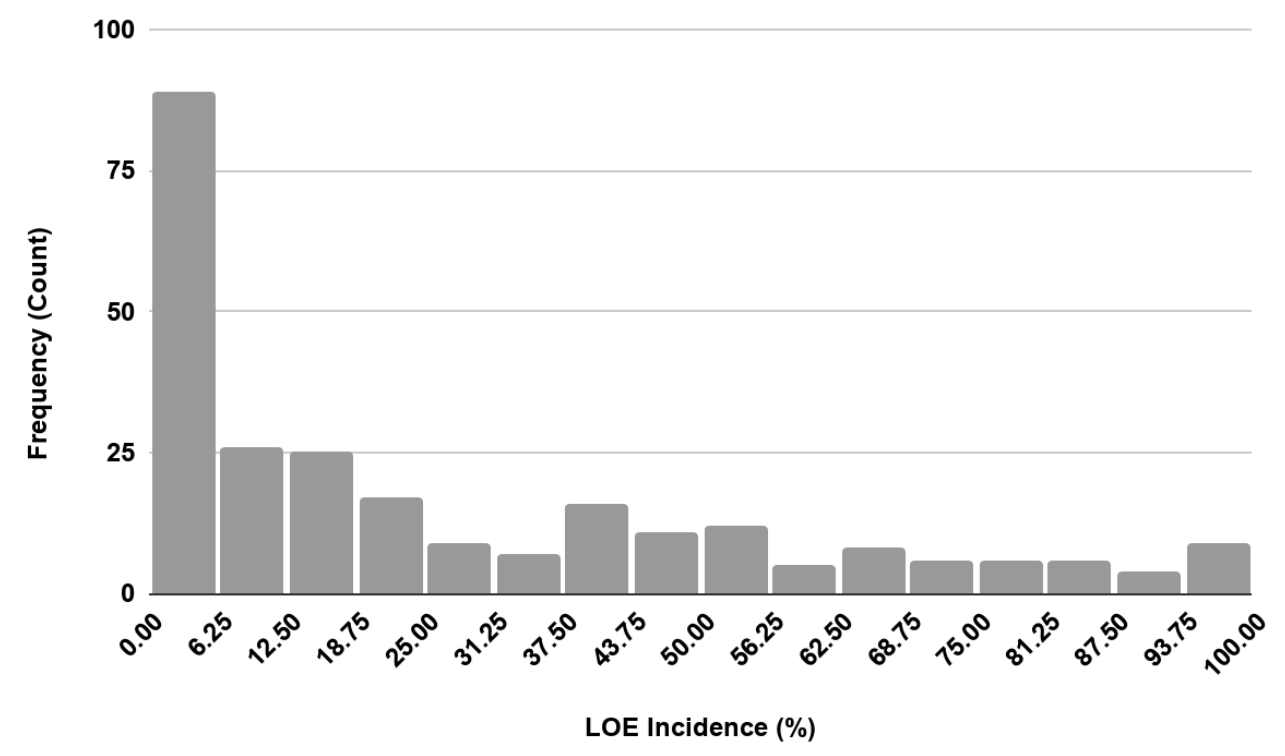

Figure 5 Distribution of LOE incidence from reported studies and timepoints extracted

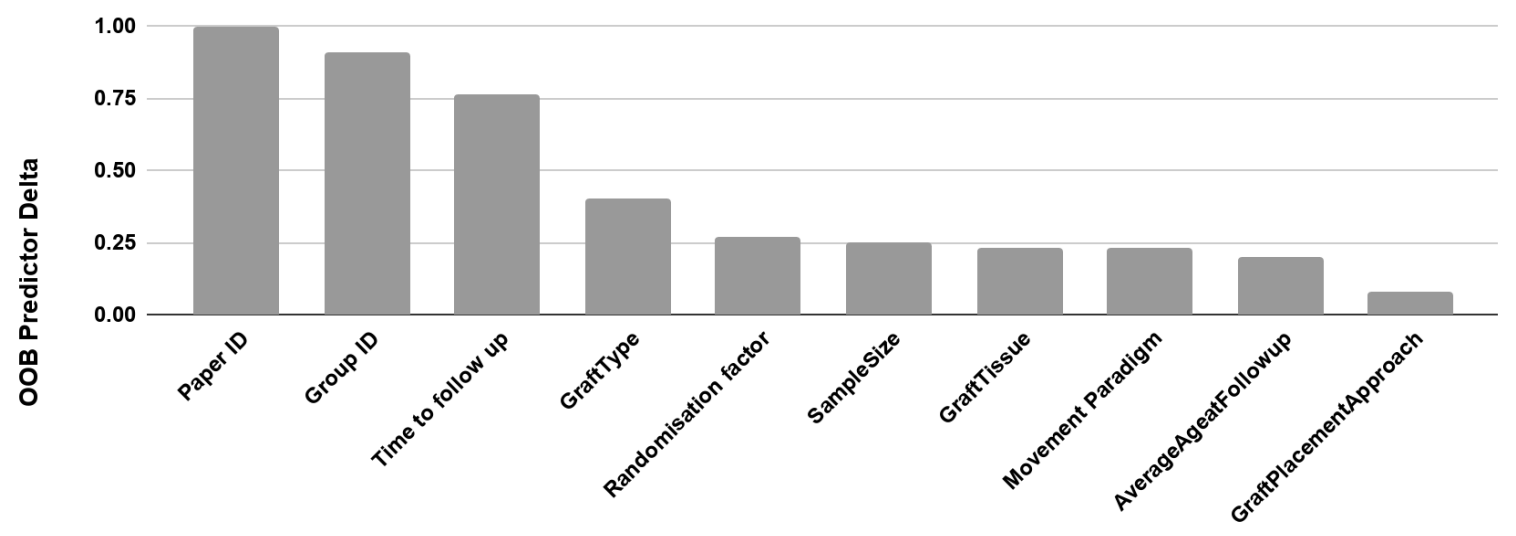

Predictor

Figure 6 Estimation of predictor importance for reduced predictor set by permutation of out-of-bag (OOB) predictor observations.

\section{Regression analysis}

After subsetting the dataset for non-zero LOE, the generalised mixed effects linear model was performed on 212 observations from 38 eligible studies, with median LOE of 21.2\% (IQR 8.4 - 50). The model provided a reasonable fit to the data (adjusted $R^{2}=55.2 \%, 4 \%$ loss from unadjusted $R^{2}$ ) and revealed a significant negative association with time to follow up (Figure 
medRxiv preprint doi: https://doi.org/10.1101/2020.11.26.20239046; this version posted November 30, 2020. The copyright holder for this preprint (which was not certified by peer review) is the author/funder, who has granted medRxiv a license to display the preprint in It is made available under a CC-BY-ND 4.0 International license.

7-left, Table F) and graft type on reported loss of extension incidence (\%) (Table F). Further analysis of graft type revealed lower incidence of LOE for allograft compared to autograft and those papers that did not report a graft type used. However, the allograft data was derived from one study comparing allograft hamstring and patellar tendon grafts. Median LOE incidence was $23 \%$ (IQR 8.4 - 50.0) for the subset of studies reporting up to 12 months of follow up (Figure 7-bottom).

Table F: Summary of coefficients from generalised linear mixed effects model. SE: Standard error; Cl: Confidence Interval.

\begin{tabular}{lccccc}
\hline Variable & $\begin{array}{c}\text { Coefficient } \\
\text { Estimate }\end{array}$ & SE & Lower 95\%Cl & Upper 95\%Cl & P-value \\
\hline ROB Overall & 7.0 & 11.2 & -15.2 & 29.1 & 0.5 \\
$\begin{array}{l}\text { Extension } \\
\begin{array}{l}\text { Threshold (30) } \\
\text { Movement }\end{array}\end{array}$ & 0.9 & 4.6 & -8.2 & 9.9 & 0.9 \\
$\begin{array}{l}\text { Paradigm } \\
\text { (seated) }\end{array}$ & 19.4 & 16.0 & -12.1 & 50.9 & 0.2 \\
$\begin{array}{l}\text { Timing of Data } \\
\text { Collection }\end{array}$ & -0.8 & 0.2 & -1.2 & -0.4 & $<0.001$ \\
$\begin{array}{l}\text { Average Age at } \\
\text { Followup }\end{array}$ & 0.5 & 1.0 & -1.6 & 2.5 & 0.7 \\
$\begin{array}{l}\text { Meniscal / } \\
\text { Cartilage Injuries } \\
\text { (not reported) }\end{array}$ & 17.4 & 13.6 & -9.4 & 44.1 & 0.2 \\
Fixation (screw) & 11.6 & 5.9 & 0.1 & 23.2 & 0.0 \\
Graft Type (allo) & -27.2 & 14.0 & -54.8 & 0.5 & 0.1 \\
$\begin{array}{l}\text { Graft Placement } \\
\text { Approach (rear) }\end{array}$ & -8.2 & 13.4 & -34.6 & 18.3 & 0.5 \\
\hline
\end{tabular}


medRxiv preprint doi: https://doi.org/10.1101/2020.11.26.20239046; this version posted November 30, 2020. The copyright holder for this preprint (which was not certified by peer review) is the author/funder, who has granted medRxiv a license to display the preprint in It is made available under a CC-BY-ND 4.0 International license .

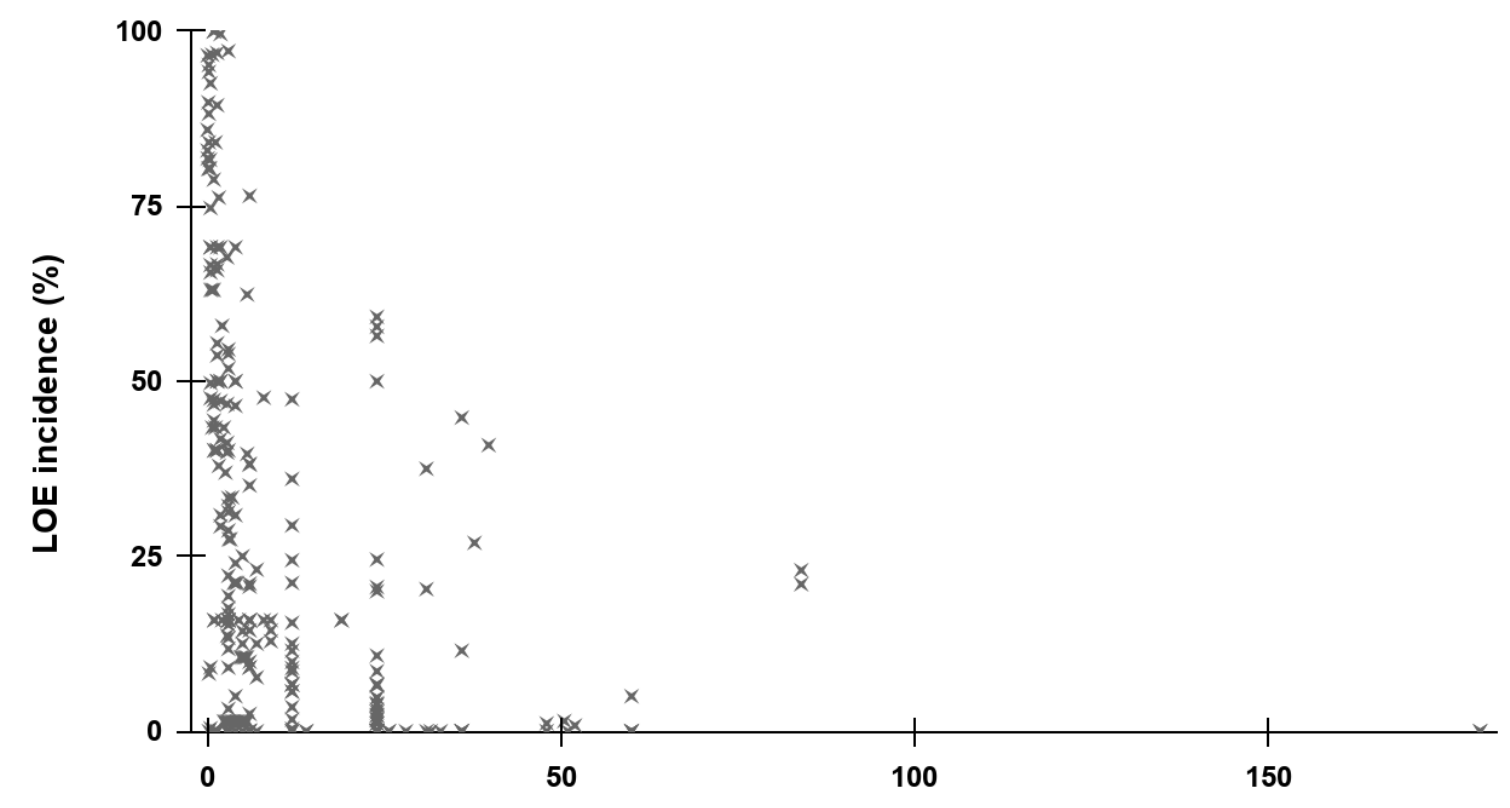

Follow up time (months)

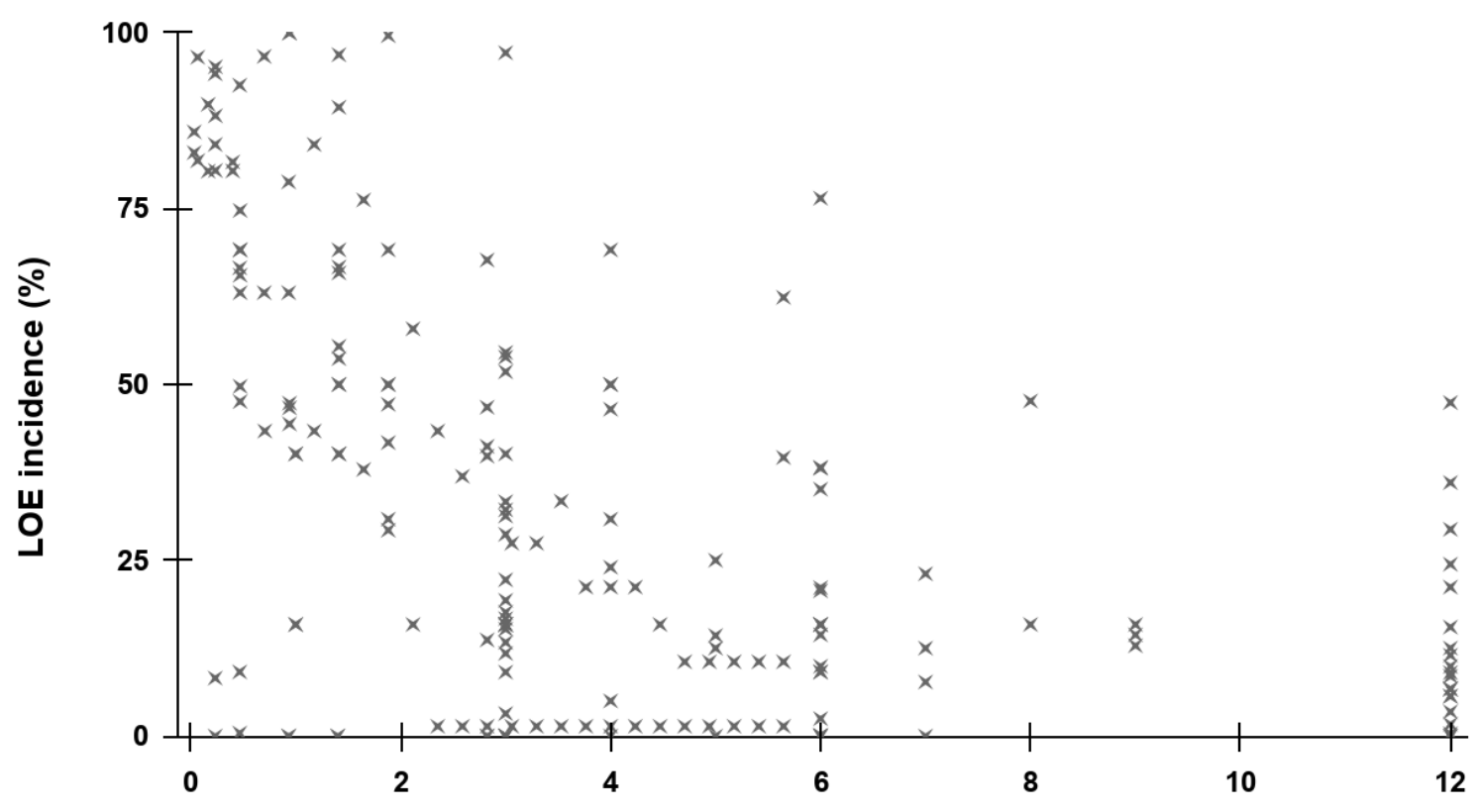

Follow up time (months)

Figure 7 Relationship between follow up time and incidence of extension deficits for all eligible data points (top) and up to 12 months follow up (bottom). 
medRxiv preprint doi: https://doi.org/10.1101/2020.11.26.20239046; this version posted November 30, 2020. The copyright holder for this preprint (which was not certified by peer review) is the author/funder, who has granted medRxiv a license to display the preprint in It is made available under a CC-BY-ND 4.0 International license .

\section{DISCUSSION}

Restoring full extension after injury to the $\mathrm{ACL}$ and its subsequent reconstruction is an important milestone in progressive rehabilitation ${ }^{72-74}$. An inability to achieve full extension, particularly under weight bearing conditions, alters the points of stress concentration between tibia and femur ${ }^{75}$ and has implications for delayed return-to-sport, patellofemoral joint pain as well as the onset of post-injury osteoarthritis ${ }^{76,77}$.

The primary objective of this review was to identify the incidence of loss of knee extension angle in patients diagnosed with $A C L$ rupture electing to undergo formal treatment under the care of a registered clinical provider (including non-operative and arthroscopic $A C L$ reconstruction) compared to the contralateral limb or control patients, as reported within randomised control studies. We report an overall median incidence of LOE of 15.9\% (IQR 1.4 - 44.7) at a median follow up from treatment of 4.8 months (IQR 1.9 - 19) across 4065 patients analysed within 48 eligible RCTs. The secondary objective of this review was to explore the manner in which knee extension deficits have been reported and defined across the literature. We have noted substantial variability within the reporting of characteristics of LOE measurement across studies, including differences in the definition of a "normal" or "full" extension comparator for determining the degree of deficit, thresholds for categorising LOE and whether the ROM was determined via an active or passive movement paradigm (Table E). Methods for determining the knee extension were also varied, with some studies reporting extension deficits through measurement of heel height difference compared to the contralateral limb, in lieu of direct measurement of plane knee angles ${ }^{31,38,40,47,67}$. Furthermore, some aspects of ROM measurements were not reported in up to $59 \%$ of papers reviewed (Table E) suggesting that a standardised framework for reporting measurement methods would be beneficial for a more accurate assessment of the incidence of LOE after ACL rupture and reconstruction.

Factors affecting the incidence of extension deficits were also examined in this systematic review. The general findings from the classification analysis revealed that the group in which 
medRxiv preprint doi: https://doi.org/10.1101/2020.11.26.20239046; this version posted November 30, 2020. The copyright holder for this preprint (which was not certified by peer review) is the author/funder, who has granted medRxiv a license to display the preprint in It is made available under a CC-BY-ND 4.0 International license .

the study participants were placed and studies themselves were the most important predictors for whether a time point was to detect an incidence of extension deficit or reported as undetected (incidence $<1 \%$ ). These results suggest that methodological differences in the papers contributed substantially to the reporting of LOE. While seemingly an obvious finding, this highlights the methodological limitations of the systematic review and potential influences of author bias, author background/specialties, interests and motivations, or regional / socioeconomic / cultural factors on the study design, and hence the detection of LOE within the cohorts of the included sample of studies. The predictor importance rankings for timing of data collection (or length of follow up), graft type and movement paradigm are further suggestive that the methodologies employed within the studies are also important determinants on reported LOE incidence.

The reduced predictor set determined by the classification analysis identified that the length of follow up may significantly influence the LOE reported in the contemporary literature $(P<$ 0.001). It appears that with short (Figure 5- right) and long term follow up (Figure 5- left), the incidence of extension deficits decrease with time. In the present review, 22 studies reported time series data for at least two timepoints. Of these, 5 studies directly reported the incidence of extension deficits for the examined groups (without a T-norm conversion) at a minimum of three months ${ }^{48,69}$ and up to two year follow up ${ }^{40,43,64}$, across 30 timepoints. For these studies specifically, we observed an overall decrease in LOE incidence, compared to the initial assessment, in $71 \%$ of time points reported, with the largest overall gain in extension $(21 \%)$ reported by Heijne and colleagues 48 in patients with bone-patellar tendon-bone grafts completing early open kinetic chain exercises for quadriceps following surgery ${ }^{48}$. A more recent study by Eriksson and colleagues ${ }^{69}$ showed a mixed response in their randomized study investigating acute versus delayed ACLR, with LOE incidence declining from 31 to $21 \%$ at the 3 to 6 month follow up respectively in patients undergoing acute ACLR, and increasing from 15 to $38 \%$ in patients who underwent a delayed reconstruction. While the results reported herein are in the context of studies that were of RCT design, others have also attempted to 
medRxiv preprint doi: https://doi.org/10.1101/2020.11.26.20239046; this version posted November 30, 2020. The copyright holder for this preprint (which was not certified by peer review) is the author/funder, who has granted medRxiv a license to display the preprint in It is made available under a CC-BY-ND 4.0 International license .

explore this issue with non-randomised designs. Noll and colleagues reported on knee extension at four, eight and 12 weeks post-ACLR in an observational cohort study, and found that with increasing time, mean knee extension also increased. Furthermore, a strong correlation between knee extension at four and twelve weeks was identified $(r=0.639, p<$ 0.001), with the investigators concluding that knee extension at four weeks post-op could be a clinical predictor for knee extension at 12 weeks ${ }^{10}$. Other prospective studies over a longer follow-up period report an incidence of only $4.2 \%$ of patients who were unable to achieve $0^{\circ}$ (neutral) extension at a mean follow up of 10.5 years ${ }^{76}$, supporting the general observations from the included RCTs within this systematic review.

The presence of LOE after ACLR is multifactorial ${ }^{7,78,79}$, with graft impingement, arthrofibrosis, suboptimal graft placement and over-tensioning of the graft among the most common reported causes ${ }^{7,78}$. While re-operation is occasionally required to treat severe extension deficits, cases where extension deficits resolve without further operative intervention and the crosssectional findings of the present review suggest there may be an innate process by which ROM is recovered. We hypothesise that in these cases where knee extension recovers spontaneously, other processes such as soft tissue remodelling may be the primary mechanism. Of particular interest to note is the significant association between graft type used in ACL reconstruction on $L O E$ incidence identified in this review, suggesting that graft type itself may contribute to the processes involved in extension recovery. However, this should be interpreted with caution due to limitations of the data analysis package which referenced the "not-reported" label for the graft type variable category, and limited number of datapoints available for analysis pertaining to studies reporting the use of allografts, which is further reflected by the wide confidence intervals observed around the fixed effect coefficient. While identifying the mechanism by which knee extension is recovered was outside the scope of this review, approximately $45 \%$ of included studies to this review were randomised based on graft type, indicating graft type remains an area of interest, and could guide future research objectives. 
medRxiv preprint doi: https://doi.org/10.1101/2020.11.26.20239046; this version posted November 30, 2020. The copyright holder for this preprint (which was not certified by peer review) is the author/funder, who has granted medRxiv a license to display the preprint in It is made available under a CC-BY-ND 4.0 International license .

While the primary focus of this systematic review was to summarise the outcomes of interest within studies of randomised controlled design to improve the body of evidence, limitations stemming from poor standardisation and reporting of measurement methods, definition of knee angle and extension comparator across studies should be considered. The t-norm conversion to estimate the incidence of LOE for studies reporting knee angle or loss of extension angle may have possibly introduced errors within the meta-analysis. When combined with the classification analysis and regression modelling, the methods described were considered most appropriate for determining overall incidence of extension deficits within the included sample of studies and for identifying factors that may be associated with the LOE incidence. However influences of general factors such as BMI or time to intervention were unable to be inferred due to the substantial rates of non-reporting, with 35 to $83 \%$ of studies not reporting the average time to intervention or height/weight respectively. Further to this, substantial risks of bias were detected across a notable number of studies, with upwards of half the included studies scoring a high risk of bias in at least one domain, or multiple judgements of some concern across multiple domains. It may be noted that knee extension angle, the degree of extension deficit or incidence of LOE were often not the primary outcome of the study, rendering them less sensitive to detecting an incidence of LOE in the study and contributing to the biases detected with respect to the measurement, presentation and reporting of findings for these metrics. We note that the limited prioritisation of knee extension as an outcome in its own right within the included randomised trials is a likely contributor to the issues identified. Other factors suspected of influence over short-term postoperative knee extension, such as graft tensioning (tension magnitude and knee angle at which tensioning is achieved) and adjunct stabilisation procedures (e.g. lateral extra-articular tenodesis), may be better explored in non-randomised investigations. Further analysis is recommended on this component of the dataset collected as part of the current work. 
medRxiv preprint doi: https://doi.org/10.1101/2020.11.26.20239046; this version posted November 30, 2020. The copyright holder for this preprint (which was not certified by peer review) is the author/funder, who has granted medRxiv a license to display the preprint in It is made available under a CC-BY-ND 4.0 International license.

\section{CONCLUSIONS}

This review established the trajectory of knee extension incidence after ACL reconstruction in studies of RCT design. Evidence of the incidence and factors associated with loss of extension were identified; however knee extension after ACL reconstruction was measured at variable time points with a variety of measurement techniques across a mixed cohort composition, with poor descriptions of how full extension was standardised. Overall, clinicians should expect up to 1 in 3 patients to present postoperatively with loss of extension of at least 3 degrees, which may partially resolve over time. Further work is required to better describe the natural history of LOE after ACL injury and reconstruction, with particular attention to the development of standardised methods and objective measurement with accepted movement paradigms and accurate quantitative tools. 
medRxiv preprint doi: https://doi.org/10.1101/2020.11.26.20239046; this version posted November 30, 2020. The copyright holder for this preprint (which was not certified by peer review) is the author/funder, who has granted medRxiv a license to display the preprint in It is made available under a CC-BY-ND 4.0 International license.

\section{Acknowledgements}

The authors would like to acknowledge the contribution of Binglong Lee, Mathew Holt, Michael Erian and Christopher Erian for their contribution to paper screening and data extraction, and Milad Ebrahimi for performing the data quality control.

\section{Protocol deviations}

- The results for the proposed systematic review protocol ${ }^{14}$ will be reported in a series of separate manuscripts categorised by study design and measurement methods. The methods and results presented herein describe the analysis of randomised control studies collected within the framework of the systematic review protocol.

- Embase via Ovid SP, Scopus and SPORTDiscus via EBSCO, AMED, CINAHL, LILACS, Scielo \& Web of Knowledge were not directly searched as per the original protocol, based on the outcome of a pilot search conducted at the commencement of the study which indicated that the articles were indexed in Cochrane and Pubmed databases already.

- ROB2.0 was used to assess risk of bias to facilitate assessment of studies of RCT design.

- Alternative software was used to conduct data analysis.

\section{Funding statement}

This research did not receive a specific grant from any funding agency in the public, commercial or not-for-profit sectors.

\section{Competing interests statement}

None declared 
medRxiv preprint doi: https://doi.org/10.1101/2020.11.26.20239046; this version posted November 30, 2020. The copyright holder for this preprint (which was not certified by peer review) is the author/funder, who has granted medRxiv a license to display the preprint in It is made available under a CC-BY-ND 4.0 International license .

\section{REFERENCES}

1. Beynnon, B. D., Johnson, R. J., Abate, J. A., Fleming, B. C. \& Nichols, C. E. Treatment of anterior cruciate ligament injuries, part I. Am. J. Sports Med. 33, 1579-1602 (2005).

2. Chalmers, P. N. et al. Does ACL reconstruction alter natural history?: A systematic literature review of long-term outcomes. J. Bone Joint Surg. Am. 96, 292-300 (2014).

3. Ardern, C. L., Taylor, N. F., Feller, J. A. \& Webster, K. E. Fifty-five per cent return to competitive sport following anterior cruciate ligament reconstruction surgery: an updated systematic review and meta-analysis including aspects of physical functioning and contextual factors. Br. J. Sports Med. 48, 1543-1552 (2014).

4. Christensen, J. E. \& Miller, M. D. Knee Anterior Cruciate Ligament Injuries: Common Problems and Solutions. Clin. Sports Med. 37, 265-280 (2018).

5. Tjoumakaris, F. P. et al. Complications in brief: Anterior cruciate ligament reconstruction. Clin. Orthop. Relat. Res. 470, 630-636 (2012).

6. Nauth, A. \& Gilbart, M. K. Knee Stiffness After Acl Reconstruction. Techniques in Knee Surgery 11, 26-33 (2012).

7. Petsche, T. S. \& Hutchinson, M. R. Loss of extension after reconstruction of the anterior cruciate ligament. J. Am. Acad. Orthop. Surg. 7, 119-127 (1999).

8. Wylie, J. D., Marchand, L. S. \& Burks, R. T. Etiologic Factors That Lead to Failure After Primary Anterior Cruciate Ligament Surgery. Clin. Sports Med. 36, 155-172 (2017).

9. Ekhtiari, S. et al. Arthrofibrosis after ACL reconstruction is best treated in a step-wise approach with early recognition and intervention: a systematic review. Knee Surg. Sports Traumatol. Arthrosc. 25, 3929-3937 (2017).

10. Noll, S., Garrison, J. C., Bothwell, J. \& Conway, J. E. Knee Extension Range of Motion at 4 Weeks Is Related to Knee Extension Loss at 12 Weeks After Anterior Cruciate Ligament Reconstruction. Orthop J Sports Med 3, 2325967115583632 (2015).

11. Robertson, G. A. J., Coleman, S. G. S. \& Keating, J. F. Knee stiffness following anterior cruciate ligament reconstruction: the incidence and associated factors of knee stiffness 
medRxiv preprint doi: https://doi.org/10.1101/2020.11.26.20239046; this version posted November 30, 2020. The copyright holder for this preprint (which was not certified by peer review) is the author/funder, who has granted medRxiv a license to display the preprint in It is made available under a CC-BY-ND 4.0 International license.

following anterior cruciate ligament reconstruction. Knee 16, 245-247 (2009).

12. Mauro, C. S., Irrgang, J. J., Williams, B. A. \& Harner, C. D. Loss of extension following anterior cruciate ligament reconstruction: analysis of incidence and etiology using IKDC criteria. Arthroscopy 24, 146-153 (2008).

13. Moher, D., Liberati, A., Tetzlaff, J., Altman, D. G. \& PRISMA Group. Preferred reporting items for systematic reviews and meta-analyses: the PRISMA statement. PLoS Med. 6, e1000097 (2009).

14. Ektas, N. et al. Recovery of knee extension and incidence of extension deficits following anterior cruciate ligament injury and treatment: a systematic review protocol. J. Orthop. Surg. Res. 14, 88 (2019).

15. O'Connor, D., Green, S. \& Higgins, J. Defining the review question and developing criteria for including studies. Cochrane handbook for systematic reviews of interventions: Cochrane book series 81-94 (2008).

16. Eaton, A. Citation-Finder. (2008). Available at https://citation-finder.now.sh/

17. Sterne, J. A. C. et al. RoB 2: a revised tool for assessing risk of bias in randomised trials. BMJ vol. 36614898 (2019).

18. Higgins, J. P. T., Thompson, S. G., Deeks, J. J. \& Altman, D. G. Measuring inconsistency in meta-analyses. BMJ: British Medical Journal 327, 557-560 (2003).

19. Egger, M., Davey Smith, G., Schneider, M. \& Minder, C. Bias in meta-analysis detected by a simple, graphical test. BMJ 315, 629-634 (1997).

20. Sachs, R. A., Daniel, D. M., Stone, M. L. \& Garfein, R. F. Patellofemoral problems after anterior cruciate ligament reconstruction. Am. J. Sports Med. 17, 760-765 (1989).

21. Neyeloff, J. L., Fuchs, S. C. \& Moreira, L. B. Meta-analyses and Forest plots using a microsoft excel spreadsheet: step-by-step guide focusing on descriptive data analysis. BMC Res. Notes 5, 52 (2012).

22. Beraha, M., Metelli, A. M., Papini, M., Tirinzoni, A. \& Restelli, M. Feature Selection via Mutual Information: New Theoretical Insights. arXiv [cs.LG] (2019).

23. Loh, W.-Y. Regression trees with unbiased variable selection and interaction detection. 
medRxiv preprint doi: https://doi.org/10.1101/2020.11.26.20239046; this version posted November 30, 2020. The copyright holder for this preprint (which was not certified by peer review) is the author/funder, who has granted medRxiv a license to display the preprint in It is made available under a CC-BY-ND 4.0 International license .

Stat. Sin. 12, 361-386 (2002).

24. Noyes, F. R., Mangine, R. E. \& Barber, S. Early knee motion after open and arthroscopic anterior cruciate ligament reconstruction. Am. J. Sports Med. 15, 149-160 (1987).

25. Richmond, J. C., Gladstone, J. \& MacGillivray, J. Continuous passive motion after arthroscopically assisted anterior cruciate ligament reconstruction: comparison of shortversus long-term use. Arthroscopy 7, 39-44 (1991).

26. Engström, B., Sperber, A. \& Wredmark, T. Continuous passive motion in rehabilitation after anterior cruciate ligament reconstruction. Knee Surg. Sports Traumatol. Arthrosc. 3, 18-20 (1995).

27. Feller, J., Bartlett, J., Chapman, S. \& Delahunt, M. Use of an extension-assisting brace following anterior cruciate ligament reconstruction. Knee Surg. Sports Traumatol. Arthrosc. 5, 6-9 (1997).

28. Zätterström, R., Fridén, T., Lindstrand, A. \& Moritz, U. Early rehabilitation of acute anterior cruciate ligament injury--a randomized clinical trial. Scand. J. Med. Sci. Sports 8, 154-159 (1998).

29. Risberg, M. A., Holm, I., Steen, H., Eriksson, J. \& Ekeland, A. The effect of knee bracing after anterior cruciate ligament reconstruction. A prospective, randomized study with two years' follow-up. Am. J. Sports Med. 27, 76-83 (1999).

30. Eriksson, K. et al. A comparison of quadruple semitendinosus and patellar tendon grafts in reconstruction of the anterior cruciate ligament. Journal of bone \& joint surgery british volume 83-B, 348-354 (2001).

31. Feller, J. A., Webster, K. E. \& Gavin, B. Early post-operative morbidity following anterior cruciate ligament reconstruction: patellar tendon versus hamstring graft. Knee Surg. Sports Traumatol. Arthrosc. 9, 260-266 (2001).

32. Möller, E., Forssblad, M., Hansson, L., Wange, P. \& Weidenhielm, L. Bracing versus nonbracing in rehabilitation after anterior cruciate ligament reconstruction: a randomized 
medRxiv preprint doi: https://doi.org/10.1101/2020.11.26.20239046; this version posted November 30, 2020. The copyright holder for this preprint (which was not certified by peer review) is the author/funder, who has granted medRxiv a license to display the preprint in It is made available under a CC-BY-ND 4.0 International license .

prospective study with 2-year follow-up. Knee Surg. Sports Traumatol. Arthrosc. 9, $102-$ 108 (2001).

33. Anderson, J. L. et al. Changes in muscle torque following anterior cruciate ligament reconstruction: a comparison between hamstrings and patella tendon graft procedures on 45 patients. Acta Orthop. Scand. 73, 546-552 (2002).

34. Henriksson, M., Rockborn, P. \& Good, L. Range of motion training in brace vs. plaster immobilization after anterior cruciate ligament reconstruction: a prospective randomized comparison with a 2-year follow-up. Scand. J. Med. Sci. Sports 12, 73-80 (2002).

35. Shaieb, M. D., Kan, D. M., Chang, S. K., Marumoto, J. M. \& Richardson, A. B. A prospective randomized comparison of patellar tendon versus semitendinosus and gracilis tendon autografts for anterior cruciate ligament reconstruction. Am. J. Sports Med. 30, 214-220 (2002).

36. Mikkelsen, C., Cerulli, G., Lorenzini, M., Bergstrand, G. \& Werner, S. Can a postoperative brace in slight hyperextension prevent extension deficit after anterior cruciate ligament reconstruction? A prospective randomised study. Knee Surg. Sports Traumatol. Arthrosc. 11, 318-321 (2003).

37. Feller, J. A. \& Webster, K. E. A randomized comparison of patellar tendon and hamstring tendon anterior cruciate ligament reconstruction. Am. J. Sports Med. 31, 564573 (2003).

38. Melegati, G. et al. The role of the rehabilitation brace in restoring knee extension after anterior cruciate ligament reconstruction: a prospective controlled study. Knee Surg. Sports Traumatol. Arthrosc. 11, 322-326 (2003).

39. McDevitt, E. R. et al. Functional bracing after anterior cruciate ligament reconstruction: a prospective, randomized, multicenter study. Am. J. Sports Med. 32, 1887-1892 (2004).

40. Aglietti, P., Giron, F., Buzzi, R., Biddau, F. \& Sasso, F. Anterior Cruciate Ligament Reconstruction: Bone-Patellar Tendon-Bone Compared with Double Semitendinosus and Gracilis Tendon Grafts. The Journal of Bone \& Joint Surgery 86, 2143-2155 (2004). 
medRxiv preprint doi: https://doi.org/10.1101/2020.11.26.20239046; this version posted November 30, 2020. The copyright holder for this preprint (which was not certified by peer review) is the author/funder, who has granted medRxiv a license to display the preprint in It is made available under a CC-BY-ND 4.0 International license.

41. Ibrahim, S. A.-R. et al. Clinical evaluation of arthroscopically assisted anterior cruciate ligament reconstruction: patellar tendon versus gracilis and semitendinosus autograft. Arthroscopy 21, 412-417 (2005).

42. Grant, J. A., Mohtadi, N. G. H., Maitland, M. E. \& Zernicke, R. F. Comparison of home versus physical therapy-supervised rehabilitation programs after anterior cruciate ligament reconstruction: a randomized clinical trial. Am. J. Sports Med. 33, 1288-1297 (2005).

43. Harilainen, A., Sandelin, J. \& Jansson, K. A. Cross-pin femoral fixation versus metal interference screw fixation in anterior cruciate ligament reconstruction with hamstring tendons: results of a controlled prospective randomized study with 2-year follow-up. Arthroscopy 21, 25-33 (2005).

44. Isberg, J. et al. Early active extension after anterior cruciate ligament reconstruction does not result in increased laxity of the knee. Knee Surg. Sports Traumatol. Arthrosc. 14, 1108-1115 (2006).

45. Lidén, M., Ejerhed, L., Sernert, N., Laxdal, G. \& Kartus, J. Patellar tendon or semitendinosus tendon autografts for anterior cruciate ligament reconstruction: a prospective, randomized study with a 7-Year follow-up. Am. J. Sports Med. 35, 740-748 (2007).

46. Järvelä, $T$. Double-bundle versus single-bundle anterior cruciate ligament reconstruction: a prospective, randomize clinical study. Knee Surg. Sports Traumatol. Arthrosc. 15, 500-507 (2007).

47. Maletis, G. B., Cameron, S. L., Tengan, J. J. \& Burchette, R. J. A prospective randomized study of anterior cruciate ligament reconstruction: a comparison of patellar tendon and quadruple-strand semitendinosus/gracilis tendons fixed with bioabsorbable interference screws. Am. J. Sports Med. 35, 384-394 (2007).

48. Heijne, A. \& Werner, S. Early versus late start of open kinetic chain quadriceps exercises after ACL reconstruction with patellar tendon or hamstring grafts: a 
medRxiv preprint doi: https://doi.org/10.1101/2020.11.26.20239046; this version posted November 30, 2020. The copyright holder for this

preprint (which was not certified by peer review) is the author/funder, who has granted medRxiv a license to display the preprint in

It is made available under a CC-BY-ND 4.0 International license .

prospective randomized outcome study. Knee Surg. Sports Traumatol. Arthrosc. 15, 402-414 (2007).

49. Siebold, R., Dehler, C. \& Ellert, T. Prospective Randomized Comparison of DoubleBundle Versus Single-Bundle Anterior Cruciate Ligament Reconstruction. Arthroscopy journal of arthroscopic and related surgery 24, 137-145 (2008).

50. Bottoni, C. R., Liddell, T. R., Trainor, T. J., Freccero, D. M. \& Lindell, K. K. Postoperative range of motion following anterior cruciate ligament reconstruction using autograft hamstrings: a prospective, randomized clinical trial of early versus delayed reconstructions. journals.sagepub.com 36, 656-662 (2008).

51. Mayr, H. O., Hochrein, A., Hein, W., Hube, R. \& Bernstein, A. Rehabilitation results following anterior cruciate ligament reconstruction using a hard brace compared to a fluid-filled soft brace. Knee 17, 119-126 (2010).

52. Raviraj, A., Anand, A., Kodikal, G., Chandrashekar, M. \& Pai, S. A comparison of early and delayed arthroscopically-assisted reconstruction of the anterior cruciate ligament using hamstring autograft. The journal of bone and joint surgery.british volume 92, 521526 (2010).

53. Grant, J. A. \& Mohtadi, N. G. H. Two- to 4-year follow-up to a comparison of home versus physical therapy-supervised rehabilitation programs after anterior cruciate ligament reconstruction. Am. J. Sports Med. 38, 1389-1394 (2010).

54. Hussein, M., van Eck, C. F., Cretnik, A., Dinevski, D. \& Fu, F. H. Prospective randomized clinical evaluation of conventional single-bundle, anatomic single-bundle, and anatomic double-bundle anterior cruciate ligament reconstruction: 281 cases with 3to 5-year follow-up. Am. J. Sports Med. 40, 512-520 (2011).

55. Noh, J. H., Yi, S. R., Song, S. J., Kim, S. W. \& Kim, W. Comparison between hamstring autograft and free tendon Achilles allograft: minimum 2-year follow-up after anterior cruciate ligament reconstruction using EndoButton and Intrafix. Knee Surg. Sports Traumatol. Arthrosc. 19, 816-822 (2011). 
medRxiv preprint doi: https://doi.org/10.1101/2020.11.26.20239046; this version posted November 30, 2020. The copyright holder for this preprint (which was not certified by peer review) is the author/funder, who has granted medRxiv a license to display the preprint in It is made available under a CC-BY-ND 4.0 International license.

56. Cappellino, F. et al. Neurocognitive rehabilitative approach effectiveness after anterior cruciate ligament reconstruction with patellar tendon. A randomized controlled trial. Eur. J. Phys. Rehabil. Med. 48, 17-30 (2012).

57. Hong, L. et al. Anterior cruciate ligament reconstruction with remnant preservation: a prospective, randomized controlled study. Am. J. Sports Med. 40, 2747-2755 (2012).

58. Ahldén, M., Sernert, N., Karlsson, J. \& Kartus, J. A prospective randomized study comparing double- and single-bundle techniques for anterior cruciate ligament reconstruction. Am. J. Sports Med. 41, 2484-2491 (2013).

59. Christensen, J. C., Goldfine, L. R. \& West, H. S. The effects of early aggressive rehabilitation on outcomes after anterior cruciate ligament reconstruction using autologous hamstring tendon: a randomized clinical trial. J. Sport Rehabil. 22, 191-201 (2013).

60. Zhu, W., Wang, D., Han, Y., Zhang, N. \& Zeng, Y. Anterior cruciate ligament (ACL) autograft reconstruction with hamstring tendons: clinical research among three rehabilitation procedures. Eur. J. Orthop. Surg. Traumatol. 23, 939-943 (2013).

61. Kang, H. J. et al. Single-bundle modified patellar tendon versus double-bundle tibialis anterior allograft ACL reconstruction: a prospective randomized study. Knee Surg. Sports Traumatol. Arthrosc. 23, 2244-2249 (2015).

62. Dai, C. et al. Arthroscopic single-bundle anterior cruciate ligament reconstruction with six-strand hamstring tendon allograft versus bone-patellar tendon-bone allograft. Knee Surg. Sports Traumatol. Arthrosc. 24, 2915-2922 (2015).

63. Koga, $\mathrm{H}$. et al. Mid- to long-term results of single-bundle versus double-bundle anterior cruciate ligament reconstruction: randomized controlled trial. Arthroscopy 31, 69-76 (2015).

64. Mohtadi, N., Chan, D., Barber, R. \& Oddone Paolucci, E. A Randomized Clinical Trial Comparing Patellar Tendon, Hamstring Tendon, and Double-Bundle ACL Reconstructions: patient-Reported and Clinical Outcomes at a Minimal 2-Year Follow- 
medRxiv preprint doi: https://doi.org/10.1101/2020.11.26.20239046; this version posted November 30, 2020. The copyright holder for this preprint (which was not certified by peer review) is the author/funder, who has granted medRxiv a license to display the preprint in It is made available under a CC-BY-ND 4.0 International license.

up. Clin. J. Sport Med. 25, 321-331 (2015).

65. Koga, $\mathrm{H}$. et al. Effect of posterolateral bundle graft fixation angles on clinical outcomes in double-bundle anterior cruciate ligament reconstruction: a randomized controlled trial. Am. J. Sports Med. 43, 1157-1164 (2015).

66. Mei, X., Zhang, Z. \& Yang, J. Double-layer versus single-layer bone-patellar tendonbone anterior cruciate ligament reconstruction: a prospective randomized study with 3year follow-up. Arch. Orthop. Trauma. Surg. 136, 1733-1739 (2016).

67. Webster, K. E., Feller, J. A., Hartnett, N., Leigh, W. B. \& Richmond, A. K. Comparison of Patellar Tendon and Hamstring Tendon Anterior Cruciate Ligament Reconstruction: a 15-Year Follow-up of a Randomized Controlled Trial. Am. J. Sports Med. 44, 83-90 (2016).

68. Mousavi, H., Maleki, A. \& Nobakht, A. Comparative Study after Hamstring Anterior Cruciate Ligament Reconstruction with Endobutton and Rigidfix: A Clinical Trial Study. Adv. Biomed. Res. 6, 136 (2017).

69. Eriksson, K., von Essen, C., Jönhagen, S. \& Barenius, B. No risk of arthrofibrosis after acute anterior cruciate ligament reconstruction. Knee Surg. Sports Traumatol. Arthrosc. 26, 2875-2882 (2018).

70. Mohtadi, N. G. \& Chan, D. S. A Randomized Clinical Trial Comparing Patellar Tendon, Hamstring Tendon, and Double-Bundle ACL Reconstructions: patient-Reported and Clinical Outcomes at 5-Year Follow-up. J. Bone Joint Surg. Am. 101, 949-960 (2019).

71. Shumborski, S. et al. A Randomized Controlled Trial of PEEK Versus Titanium Interference Screws for Anterior Cruciate Ligament Reconstruction With 2-Year Followup. Am. J. Sports Med. 47, 2386-2393 (2019).

72. Cavanaugh, J. T. \& Powers, M. ACL Rehabilitation Progression: Where Are We Now? Curr. Rev. Musculoskelet. Med. 10, 289-296 (2017).

73. Wilk, K. E., Macrina, L. C., Cain, E. L., Dugas, J. R. \& Andrews, J. R. Recent advances in the rehabilitation of anterior cruciate ligament injuries. J. Orthop. Sports Phys. Ther. 
medRxiv preprint doi: https://doi.org/10.1101/2020.11.26.20239046; this version posted November 30, 2020. The copyright holder for this preprint (which was not certified by peer review) is the author/funder, who has granted medRxiv a license to display the preprint in It is made available under a CC-BY-ND 4.0 International license.

42, 153-171 (2012).

74. Manske, R. C., Prohaska, D. \& Lucas, B. Recent advances following anterior cruciate ligament reconstruction: rehabilitation perspectives : Critical reviews in rehabilitation medicine. Curr. Rev. Musculoskelet. Med. 5, 59-71 (2012).

75. Titchenal, M. R., Chu, C. R., Erhart-Hledik, J. C. \& Andriacchi, T. P. Early Changes in Knee Center of Rotation During Walking After Anterior Cruciate Ligament Reconstruction Correlate With Later Changes in Patient-Reported Outcomes. Am. J. Sports Med. 45, 915-921 (2017).

76. Shelbourne, K. D., Urch, S. E., Gray, T. \& Freeman, H. Loss of Normal Knee Motion After Anterior Cruciate Ligament Reconstruction Is Associated With Radiographic Arthritic Changes After Surgery. Am. J. Sports Med. 40, 108-113 (2011).

77. Shelbourne, K. D., Freeman, H. \& Gray, T. Osteoarthritis after anterior cruciate ligament reconstruction: the importance of regaining and maintaining full range of motion. Sports Health 4, 79-85 (2012).

78. Magit, D., Wolff, A., Sutton, K. \& Medvecky, M. J. Arthrofibrosis of the knee. J. Am. Acad. Orthop. Surg. 15, 682-694 (2007).

79. Austin, J. C., Phornphutkul, C. \& Wojtys, E. M. Loss of knee extension after anterior cruciate ligament reconstruction: effects of knee position and graft tensioning. J. Bone Joint Surg. Am. 89, 1565-1574 (2007). 